\title{
Evaluation of entomopathogenic nematodes under laboratory and greenhouses conditions for the control of Spodoptera frugiperda
}

\author{
Avaliação de nematoides entomopatogênicos em condições de laboratório e casa-de-vegetação visando ao \\ controle de Spodoptera frugiperda
}

\author{
Vanessa Andaló ${ }^{I *}$ Viviane Santos ${ }^{\mathrm{II}}$ Grazielle Furtado Moreira ${ }^{\mathrm{I}}$ Camila Costa Moreira ${ }^{\mathrm{I}}$ \\ Alcides Moino Junior ${ }^{\mathrm{I}}$
}

\begin{abstract}
The increased corn planting grown in the late season crop and the use of a notillage planting system benefits the development of Spodoptera frugiperda, the main pest of corn crop. Thus, this study aimed to select entomopathogenic nematodes based on the mortality of $\boldsymbol{S}$. frugiperda, and to adjust the nematode concentrations in the laboratory and evaluate the action of these organisms in greenhouse conditions. Seventeen nematode populations were tested at concentrations of 100, 250, and 500 infective juveniles (IJ)/larvae. The obtained data were submitted to the polynomial regression test. In the greenhouse, corn sowing was performed in plastic buckets with soil, corn straw, and water. After 7 days, Steinernema arenarium or Heterorhabditis sp. RSCO2, and the larvae were added $(40$ larvae, one larvae/repetition). The data were submitted to the variance analysis and the Scott-Knott test $(P<0.05)$. In the laboratory, tests with $S$. arenarium and Heterorhabditis $s p$. RSCO2 caused mortality of 85 and $90 \%$, respectively, being selected for the concentrations test. Concentrations of 150, 200, 250, 300, and 350IJ larvae ${ }^{-1}$ were tested. At a concentration of $200 I J$ larvae $^{-1}$, S. arenarium and Heterorhabditis sp. RSCO2 caused 100 and $97.6 \%$ mortality in laboratory, respectively, and in the greenhouse caused 77.5 and $87.5 \%$ mortality, respectively, when compared to the control (7.5\%).
\end{abstract}

Key words: biological control, fall army worm, Heterorhabditis, Steinernema.

\section{RESUMO}

$O$ aumento no plantio do milho "safrinha" $e$ o uso do sistema de plantio direto favorecem o desenvolvimento de Spodoptera frugiperda, principal praga da cultura. Dessa forma, os objetivos deste trabalho foram selecionar nematoides entomopatogênicos, de acordo com a mortalidade causada sobre S. frugiperda, adequar as concentrações em laboratório e avaliar a ação desses organismos em condições de casa-devegetação. Foram testadas 17 populações de nematoides nas concentrações de 100, 250 e 500 juvenis infectantes (JI) lagarta${ }^{1}$. Os dados obtidos foram submetidos ao teste de regressão polinomial. Em casa-de-vegetação, a semeadura do milho foi realizada em vasos de plástico contendo solo, palhada de milho e água. Após sete dias, foram adicionados Steinernema arenarium ou Heterorhabditis sp. RSCO2 e as lagartas (40 lagartas, uma lagarta/repetição). Os dados obtidos foram submetidos à análise de variância e ao teste de médias ScottKnott $(P<0,05)$. Nos testes de laboratório, S. arenarium $e$ Heterorhabditis sp. RSC02 causaram mortalidade de 85 e $90 \%$, respectivamente, sendo selecionados para o teste de concentrações. Foram testadas as concentrações de 150, 200, 250, 300 e 350JI lagarta ${ }^{-1}$. Na concentração de 200JI lagarta ${ }^{-1}$, S. arenarium e Heterorhabditis sp. RSC02 causaram $100 e$ $97,6 \%$ de mortalidade, respectivamente, e em casa-devegetação causaram 77,5 e $87,5 \%$, respectivamente, diferindo da testemunha $(7,5 \%)$.

Palavras-chave: controle biológico, lagarta-do-cartucho, Heterorhabditis, Steinernema.

\section{INTRODUCTION}

The caterpillar armyworm, Spodoptera frugiperda (Smith, 1797) (Lepidoptera: Noctuidae), is the principal pest of corn in Brazil. The increased corn planting grown in the late season crop and the use of a

'Departamento de Entomologia, Universidade Federal de Lavras (UFLA), CP 3037, 37200-000, Lavras, MG, Brasil. E-mail: vanessaandalo@yahoo.com.br. *Autor para correspondência.

IIDepartamento de Entomologia e Acarologia, Escola Superior de Agricultura Luiz de Queiroz (ESALQ), Universidade de São Paulo (USP), Piracicaba, SP, Brasil. 
notillage system benefit the development of larvae and hinder its control, increasing the severity of caterpillar armyworm infestation in cultivated areas. With the availability of food during the entire year, the pest has numerous conditions for survival. The insect pest also attacks and causes injuries to several other cultivars of economic importance such as cotton, rice, alfalfa, peanuts, squash, potato, collard green, spinach, bean, cabbage, sorghum, wheat, and tomato (CRUZ \& MONTEIRO, 2004).

The occurrence of $\boldsymbol{S}$. frugiperda causes considerable production loss to the corn crops, since the pest can vary in choice of cultivar used, phenological stage, production system employed and location of the plantation. Larvae preferentially feed on the cartridge of the plant and later become pupae in the soil; however, its presence can occur throughout the crop cycle, which increases damage to the crop (SARMENTO et al., 2002).

The main method used to control has been the use of chemical insecticides; however, the abusive and careless use of these insecticides has brought about serious problems that are derived from a lack of specificity of the product, and accumulation in the environment that lead to pollution problems and to the development of resistant populations (PFEIFER \& GRIGEIATTI, 1996; NERI et al., 2005).

Several entomopathogenic organisms can be used in pest control, such as fungi, viruses and bacteria (VALADARES-INGLIS et al., 1998). Among those organisms studied for $\boldsymbol{S}$. frugiperda population control, the entomopathogenic nematodes EN present a great potential for the planting system, notillage system, due to its favorable environment, which facilitates the maintenance of EN in the area and keeps them viable and pathogenic (GREWAL et al., 2001).

Before field tests, the nematode populations should be evaluated in relation to their virulence against the target-insect, since there is evidence that the nematode populations have different virulence from the hosts. The ideal concentration of EN that causes pest mortality also changes (KAYA \& HARA, 1981; FUXA et al., 1988). Therefore, we aimed to select EPN based on the mortality of $\boldsymbol{S}$. frugiperda and to adjust the concentration of nematodes in the laboratory and evaluate the action of these organisms in greenhouse conditions.

\section{MATERIAL AND METHODS}

Multiplication and maintenance of the entomopathogenic nematodes

The nematodes were obtained from the Insect Pathology Laboratory, Entomology Department of the Federal University of Lavras (MG), and were maintained in Erlenmeyer flasks in acclimatized chambers at a temperature of $16 \pm 1^{\circ} \mathrm{C}$, in an aqueous suspension with 500 to 1,000 infective juveniles (IJ) $\mathrm{ml}^{-1}$.

The nematodes were grown on Galleria mellonella larvae (Linnaeus, 1758) (Lepidoptera: Pyralidae) grown in the Insect Pathology Laboratory, according to the methodology described by DUTKY et al. (1964), using an artificial diet modified by PARRA (1998).

Ten G. mellonella larvae of the last instar were transferred to Petri dishes ( $9 \mathrm{~cm}$ in diameter) with filter paper on the bottom, to multiply the EN species used in this study, according to MOLINA \& LÓPEZ (2001) methodology. In subsequent steps, $1 \mathrm{ml}$ of the nematode suspension was added at a concentration of $20 \mathrm{IJ}$ larvae ${ }^{-1}$. The dishes were kept in chambers for 72 hours at $24 \pm 1^{\circ} \mathrm{C}$ and 24 hours of darkness. After mortality confirmation through the characteristic symptoms, the larvae were transferred to a dry storage room for 4 days.

After this period, the larvae were transferred to the White trap (WHITE, 1927) to collect the IJ from the nematodes. The traps were maintained in acclimatized chambers for 3 to 7 days under the same conditions that were previously described. The IJ suspension was collected daily and transferred to a tube $(1 \mathrm{~L})$ containing $800 \mathrm{ml}$ of distilled water, allowing the IJ to decant for 24 hours. The decantation process was performed to separate the fatty insect bodies from the IJ. After completion of the nematode suspension purification process, these were diluted and quantified in plastic plates for serologic tests (ELISA) with a stereoscopic microscope.

\section{Spodoptera frugiperda growth}

To establish the initial $S$. frugiperda colony, larvae were collected from areas of corn cultivars in the region of Lavras, MG, and then placed into test tubes of $15 \mathrm{~cm}$ in height and $1.5 \mathrm{~cm}$ in diameter, containing an artificial diet (BOWLING, 1967).

After transforming into pupae, they were sexed and transferred to PVC tubes of $10 \mathrm{~cm}$ in diameter and $20 \mathrm{~cm}$ in height, with the tube extremities plugged with a voile-type fabric and sealed with elastic. The tubes were internally coated with filter paper so that the females could oviposition, just after the emergence of adults. The moths were fed daily with $10 \%$ honey placed into the tube with cotton so that they could obtain the food. The postures were transferred to sterilized Petri dishes with an artificial diet and, when the newly hatched caterpillars were later obtained, they were individualized in test tubes with the same diet. 
Selection of the entomopathogenic nematodes

For the selection of EN in relation to $S$.

frugiperda virulence, 17 populations at the concentration of 100, 250 and 500IJ larvae ${ }^{-1}$ were tested (Table 1). Fourth or fifth instar larvae were individualized in Petri dishes ( $5 \mathrm{~cm}$ in diameter) containing filter paper and an artificial diet with a total of 20 larvae per treatment. A $1 \mathrm{ml}$ nematode suspension was applied to the different concentrations. The experiment was conducted with 20 repetitions/treatment, with different nematode and control populations, where the control received the same volume of distilled water in place of the nematode application. The plates were maintained in acclimatized chambers at $24 \pm 1^{\circ} \mathrm{C}$, and the evaluation was completed 3 days after the nematode application. To confirm mortality and verify the presence of nematodes the larvae were dissected. The data were submitted to the variance analysis and the Scott-Knott test $(\mathrm{P}<0.05)$ to compare the means.

Adequacy of the entomopathogenic nematode concentration

To identify the proper concentration of IJ suspension to be applied in $S$. frugiperda, two nematodes were tested. Steinernema arenarium A11 (Artyukhovsky, 1967) Wouts, Mracek, Gerdin \& Bedding, 1982 and Heterorhabditis sp. RSC02 were selected in a previous assay according to the mortality percentage that was caused in the larvae. Concentrations of 150, 200, 250, 300 and 350IJ larvae ${ }^{-1}$ were tested, following methodology similar to that used

Table 1 - Populations of native and exotic entomopathogenic nematodes (Rhabditida: Heterorhabditidae and Steinernematidae) used in the experiment.

\begin{tabular}{ll}
\hline Nematode & Origin \\
\hline Steinernema arenarium & Voronezh/Russia \\
Steinernema carpocapsae All & North Carolina/USA \\
Steinernema feltiae Sn & Florida/USA \\
Steinernema glaseri NA & Florida/USA \\
Steinernema riobrave 355 & Texas/ USA \\
Heterorhabditis bacteriophora HP88 & New Jersey/ USA \\
Heterorhabditis sp. JPM3 & Lavras/MG/Brazil \\
Heterorhabditis sp. JPM3.1 & Lavras/MG/ Brazil \\
Heterorhabditis sp. JPM4 & Lavras/MG/ Brazil \\
Heterorhabditis sp. PI & Teresina/Piauí/ Brazil \\
Heterorhabditis sp. RSC01 & Benjamin Constant/AM/ Brazil \\
Heterorhabditis sp. RSC02 & Benjamin Constant/AM/ Brazil \\
Heterorhabditis sp. RSC03 & Benjamin Constant/AM/ Brazil \\
Heterorhabditis amazonensis RSC05 & Benjamin Constant/AM/ Brazil \\
Heterorhabditis sp. Nepet 11 & Palmeira das Missões/RS/ Brazil \\
Heterorhabditis sp. SG & Lavras/MG/ Brazil \\
Heterorhabditis sp. AL & Lavras/MG/ Brazil \\
\hline
\end{tabular}

in the previous assay; however, 25 larvae were used per treatment in the application of the two selected nematodes and for the control, where only distilled water was applied. The larvae dissection was performed to verify the presence of nematodes. The data obtained were submitted to the polynomial regression analysis. The selected concentration for use in the following tests was obtained through calculation of the maximum point for each nematode.

Greenhouse test

Corn planting was performed in 2 liters plastic vessels containing $1.5 \mathrm{~kg}$ of soil (dark red latosol) covered with $2.5 \mathrm{~cm}$ of corn straw, with $200 \mathrm{ml}$ of water. The vessels were closed using three wood supports on the top edges, and then sealed with a voile-type fabric and elastic. After 7 days, when the seedling reached a size of approximately $10 \mathrm{~cm}, 100 \mathrm{ml}$ of water was added, and the previously selected nematodes were applied on the soil in the quantity of $1,655 \mathrm{IJ} \mathrm{vessel}^{-1}$ (according to the concentration established by the previous assay, relating the number of IJ applied in the dish and correlating with the area of the vessel). In the following sequence, 40 larvae (one larvae/repetition) were placed in the containers and they were covered again. Only water without nematodes was applied to the control. The containers were maintained under greenhouse conditions at an average temperature of $27.4^{\circ} \mathrm{C}$, and an average relative humidity of $62 \%$. The evaluations were performed after 4 days, and the number of larvae killed by the nematodes was observed; dissection of the corpses was also performed to confirm that death was in fact caused by the nematodes. The mortality data were corrected by using the Abbott formula (ABBOTT, 1925), and were submitted to variance analysis and to the Scott-Knott test $(\mathrm{P}<0.05)$ for comparisons between the means.

\section{RESULTS AND DISCUSSIONS}

Selection of entomopathogenic nematodes

There was no predominance of the

Steinernema or Heterorhabditis nematode genus in relation to the greater mortality caused in $S$. frugiperda. The Heterorhabditis sp. RSC01 and Steinernema riobrave Cabanillas, Poinar and Raulston, 1994 nematodes caused the smallest percentage of mortality in the three tested concentrations. No mortality was observed in the control treatment, and thus, all of the tested nematodes were determined to be pathogenic to the $S$. fugiperda larvae (Table 2).

Ciência Rural, v.40, n.9, set, 2010. 
The Heterorhabditis sp. RSC02 nematode caused greater mortality to $S$. frugiperda at a concentration of 100IJ larvae ${ }^{-1}$, when compared to many of the other nematodes, except to Heterorhabditis sp. Nepet11, Heterorhabditis sp. AL and S. arenarium. The mortality was even greater when a concentration of 250IJ larvae ${ }^{-1}$ was tested; however, when 500IJ larvae ${ }^{-1}$ was tested, the mortality concentration remained the same of when was used 250IJ larvae ${ }^{-1}$ (Table 2).

For the $S$. arenarium nematode, the mortality percentage caused in $S$. frugiperda was increased as a function of the increase in the IJ larvae ${ }^{-1}$ concentration. At a concentration of 100IJ larvae ${ }^{-1}$, the nematode caused the greatest mortality, together with Heterorhabditis sp. Nepet 11 and Heterorhabditis $s p$. $A \mathrm{~L}$ (Table 2). Thus, the $\boldsymbol{S}$. arenarium and Heterorhabditis $s p$. RSC02 nematodes, which caused mortality of 85 and $90 \%$, respectively, at a concentration of 250IJ larvae ${ }^{-1}$, were selected for completion of the latter concentration adequacy and greenhouse tests.

The results demonstrate the difference of virulence among the nematode populations. The same results were observed by FUXA et al. (1988), who evaluated the effect of different populations of Steinernema feltie (Filipjev, 1934) Wouts, Mracek, Gerdin and Boemare, 1982, on S. frugiperda and obtained variations in the percentage of larvae mortality.
The ability to infect and cause mortality in S. frugiperda was also observed by MOLINA-OCHOA et al. (1996). They studied the efficiency of different entomopathogenic nematode species on S. frugiperda, and confirmed that the Heterorhabditis bacteriophora was the most efficient when considering the larval phase, causing $65 \%$ mortality in second instar larvae.

Adequacy of the entomopathogenic nematodes concentration

To test the concentration adequacy of the IJ of S. arenarium and Heterorhabditis sp. RSC02 that were applied per larvae of $\boldsymbol{S}$. fugiperda, similar regression curves were observed for both nematodes. There was an accentuated increase in the mortality percentage of $\boldsymbol{S}$. frugiperda until a concentration of 150IJ larvae ${ }^{-1}$; after this concentration, a small progression was observed when a concentration of 200IJ larvae ${ }^{-1}$ was tested. However, concentrations above 200 did not have an increase in the mortality percentage (Figure 1).

The concentration of 200IJ larvae ${ }^{-1}$ for $S$. arenarium caused $100 \%$ mortality, and for Heterorhabditis sp. RSC02 caused $97.6 \%$ mortality. In concentrations greater than 250IJ larvae ${ }^{-1}$, an elevated mortality percentage was not observed. At the 300IJ larvae ${ }^{-1}$ concentration, this percentage decreased for S. arenarium (Figure 1).

Table 2 - Percentage of total mortality confirmed of Spodoptera frugiperda 4 days after entomopathogenic nematode inoculation.

\begin{tabular}{|c|c|c|c|}
\hline \multirow{2}{*}{ Treatment } & \multicolumn{3}{|c|}{ 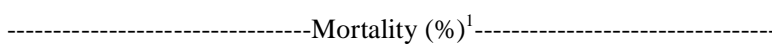 } \\
\hline & 100IJ larvae le $^{-1}$ & 250IJ larvae ${ }^{-1}$ & 500IJ larvae \\
\hline Heterorhabditis sp. RSC02 & $85 \pm 10.0 \mathrm{~A} \mathrm{a}$ & $90 \pm 11.5 \mathrm{~A} \mathrm{a}$ & $90 \pm 11.5 \mathrm{~A} \mathrm{a}$ \\
\hline Heterorhabditis sp. AL & $80 \pm 16.3 \mathrm{~B} \mathrm{a}$ & $75 \pm 10.0 \mathrm{~B} \mathrm{~b}$ & $95 \pm 10.0 \mathrm{~A} \mathrm{a}$ \\
\hline Heterorhabditis sp. Nepet 11 & $80 \pm 16.3 \mathrm{~A} \mathrm{a}$ & $75 \pm 10.0 \mathrm{~A} \mathrm{~b}$ & $70 \pm 11.5 \mathrm{~A} \mathrm{c}$ \\
\hline Steinernema arenarium & $80 \pm 0.0 \quad \mathrm{~B} \mathrm{a}$ & $85 \pm 10.0 \mathrm{~B} \mathrm{~b}$ & $95 \pm 10.0 \mathrm{~A} \mathrm{a}$ \\
\hline Heterorhabditis sp. PI & $75 \pm 10.0 \mathrm{~B} \mathrm{~b}$ & $95 \pm 10.0 \mathrm{~A} \mathrm{a}$ & $95 \pm 10.0 \mathrm{~A} \mathrm{a}$ \\
\hline Steinernema carpocapsae & $75 \pm 10.0 \mathrm{~B} \mathrm{~b}$ & $85 \pm 10.0 \mathrm{~A} \mathrm{~b}$ & $90 \pm 11.5 \mathrm{~A} \mathrm{a}$ \\
\hline Heterorhabditis sp. RSC03 & $75 \pm 10.0 \mathrm{~B} \mathrm{~b}$ & $80 \pm 16.3 \mathrm{~B} \mathrm{~b}$ & $90 \pm 11.5 \mathrm{~A} \mathrm{a}$ \\
\hline Heterorhabditis sp. SG & $70 \pm 11.5 \mathrm{~B} \mathrm{~b}$ & $80 \pm 16.3 \mathrm{~A} \mathrm{~b}$ & $85 \pm 10.0 \mathrm{~A} \mathrm{~b}$ \\
\hline Heterorhabditis amazonensis RSC05 & $70 \pm 11.5 \mathrm{~B} \mathrm{~b}$ & $85 \pm 10.0 \mathrm{~A} \mathrm{~b}$ & $95 \pm 11.5 \mathrm{~A} \mathrm{a}$ \\
\hline Heterorhabditis bacteriophora HP88 & $65 \pm 10.0 \mathrm{~B} \mathrm{~b}$ & $95 \pm 10.0 \mathrm{~A} \mathrm{a}$ & $85 \pm 10.0 \mathrm{~A} \mathrm{~b}$ \\
\hline Steinernema feltiae & $65 \pm 10.0 \mathrm{~B} \mathrm{~b}$ & $80 \pm 16.3 \mathrm{~A} \mathrm{~b}$ & $80 \pm 16.3 \mathrm{~A} \mathrm{~b}$ \\
\hline Heterorhabditis sp. JPM4 & $65 \pm 10.0 \mathrm{~B} \mathrm{~b}$ & $75 \pm 10.0 \mathrm{~A} \mathrm{~b}$ & $80 \pm 16.3 \mathrm{~A} \mathrm{~b}$ \\
\hline Heterorhabditis sp. JPM 3.1 & $55 \pm 10.0 \mathrm{~B} \mathrm{c}$ & $60 \pm 11.5 \mathrm{~B} \mathrm{c}$ & $70 \pm 11.5 \mathrm{~A} \mathrm{c}$ \\
\hline Steinernema glaseri & $55 \pm 10.0 \mathrm{~B} \mathrm{c}$ & $75 \pm 10.0 \mathrm{~A} \mathrm{~b}$ & $85 \pm 10.0 \mathrm{~A} \mathrm{~b}$ \\
\hline Steinernema riobrave & $45 \pm 10.0 \mathrm{~B} \mathrm{~d}$ & $60 \pm 16.3 \mathrm{~A} \mathrm{c}$ & $65 \pm 10.0 \mathrm{~A} \mathrm{c}$ \\
\hline Heterorhabditis sp. RSC01 & $40 \pm 0.0 \quad \mathrm{~A} \mathrm{~d}$ & $45 \pm 10.0 \mathrm{~A} \mathrm{~d}$ & $45 \pm 10.0 \mathrm{~A} \mathrm{~d}$ \\
\hline Heterorhabditis sp. JPM3 & $40 \pm 16.3 \mathrm{~B} \mathrm{~d}$ & $70 \pm 11.5 \mathrm{~A} \mathrm{c}$ & $80 \pm 16.3 \mathrm{~A} \mathrm{~b}$ \\
\hline Control & $0 \pm 0 \quad \mathrm{~A} \mathrm{e}$ & $0 \pm 0 \quad \mathrm{~A} \mathrm{e}$ & $0 \pm 0 \quad \mathrm{~A} \mathrm{e}$ \\
\hline
\end{tabular}

${ }^{1}$ Means with capital letters for the comparison of means in the lines, and lowercase letter in the columns differ among themselves by the Scott-Knott test $(\mathrm{P}<0.05)$. 


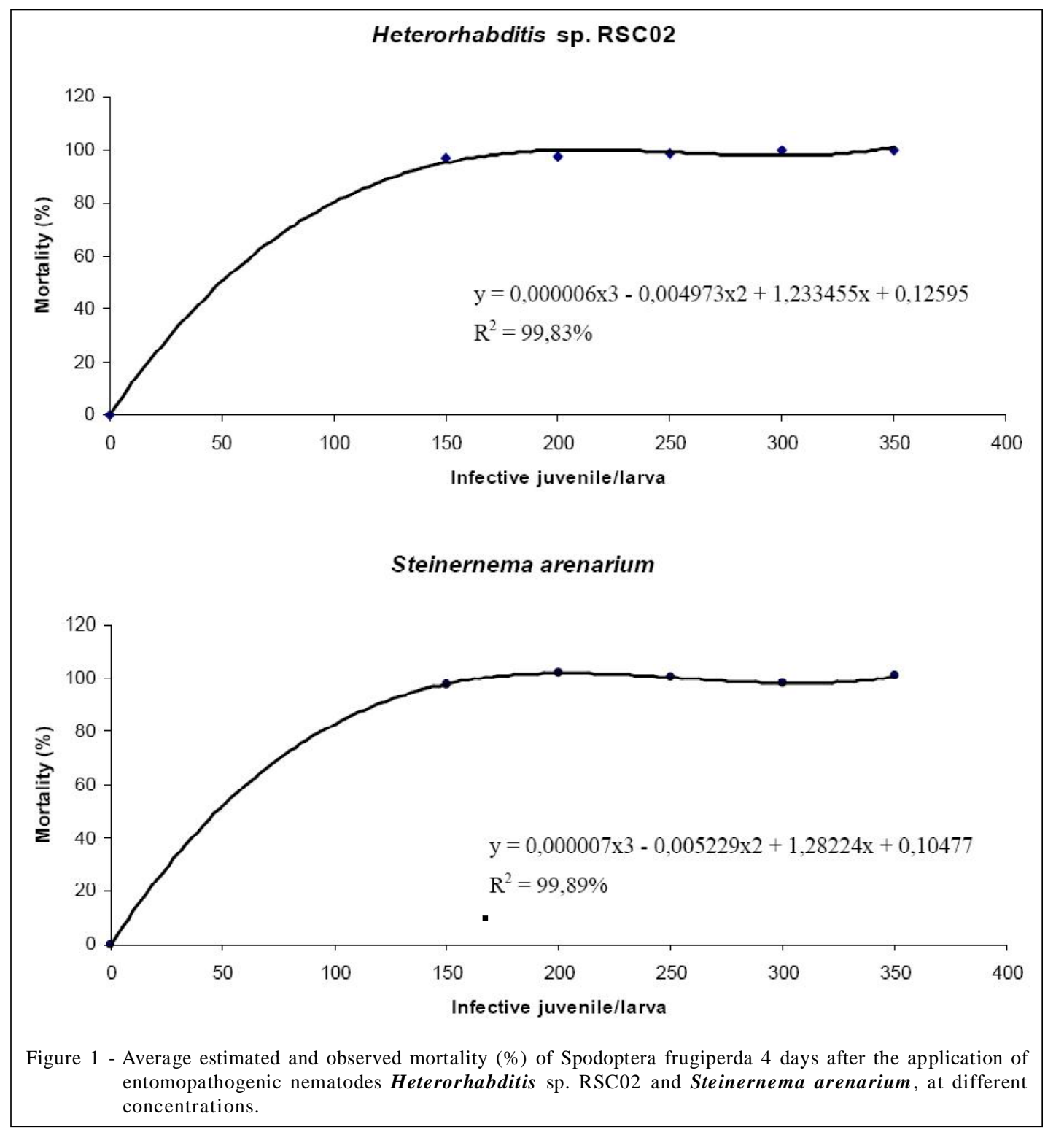

The maximum mortality points of the tested concentrations were calculated for both nematodes; Heterorhabditis sp. RSC02 had a maximum mortality of 223IJ larvae ${ }^{-1}$ and $S$. arenarium had a maximum mortality of 218IJ larvae ${ }^{-1}$. Thus, the concentration of 200IJ larvae ${ }^{-1}$ was determined to be the ideal concentration for the greenhouse test.

In relation to the high nematode activity for the caterpillar armyworm (up to $100 \%$ mortality), these data agree with results obtained by MOLINA-OCHOA et al. (1996). After studying different nematodes, the authors verified that $\boldsymbol{H}$. bacteriophora, at a concentration of $100 \mathrm{IJ} \mathrm{ml}^{-1}$, caused mortality in $64.7 \%$ of S. frugiperda larvae.
The data presented here are in agreement with the research of FUXA et al. (1988), which verified that the mortality percentage caused by $S$. feltiae in $S$. frugiperda larvae increases with an increased concentration of applied IJ suspension, until a certain concentration, and after that there is a decrease in mortality.

Greenhouse test

In the greenhouse tests, the $\boldsymbol{S}$. arenarium and Heterorhabditis sp. RSC02 nematodes caused 75.7 and 86.5 mortality, respectively (Table 3 ). Therefore, the nematodes were capable of causing mortality in $S$. frugiperda in the tested conditions, demonstrating a potential for later tests under field conditions. 
The larvae mortality was evaluated 7 days after the IJ inoculation, a period that should be observed to properly manage the culture. KOPPENHÖFER et al. (1999) highlighted the possibility of using control agent groups with synergic effects, such as EN and Bacillus thuringiensis, which causes stress to the inoculated larvae due to the presence of pathogens, and thus, the larvae become more susceptible to the action of later applied nematodes, assisting with a more rapid mortality of the pest. This outcome is due to the high mortality caused by the involved agents (BAUR et al., 1998).

Factors like humidity and soil type, environmental conditions, and manner of application can also affect EN action. Thus, in field conditions, due to the complexity of factors in the agriculture systems with constant use of bio-insecticides, and where the pests are regulated by other pathogens, studies must be adjusted to confirm the potential of this method of control (GARCIA et al., 2008).

The use of EN to control $S$. frugiperda showed potential in the present research when were tested in greenhouse, however, field tests should be performed in order to focus on correct time and application of this organisms, so that the nematode is able to find the larvae on the soil, which occurs mainly in no-tillage system, widely used today, mainly in the cultivation of corn planting season, which is showing serious problems with $\boldsymbol{S}$. frugiperda.

\section{CONCLUSION}

The obtained results demonstrate the possibility of using the ENs as biological control agents of S. frugiperda. Steinernema arenarium and Heterorhabditis sp. RSC02 nematodes were considered to be the most virulent, and through the concentration test it was possible to reduce the quantity of the applied IJ per larvae in the greenhouse test.

Table 3 - Confirmed and correct mortality percentage of Spodoptera frugiperda 7 days after inoculation of the entomopathogenic nematodes Steinernema arenarium and Heterorhabditis sp. $\mathrm{RSC} 2$, in greenhouse conditions.

\begin{tabular}{ll}
\hline Treatment & Mortality $(\%)^{1,2}$ \\
\hline Control & $0 \pm 0 \mathrm{a}$ \\
Steinernema arenarium & $75.7 \pm 9.5 \mathrm{~b}$ \\
Heterorhabditis sp. RSC02 & $86.5 \pm 9.5 \mathrm{~b}$ \\
\hline
\end{tabular}

${ }^{1}$ Means following the same letter in the column do not differ among themselves by the Scott-Knott test $(\mathrm{P}<0.05)$.

${ }^{2}$ Corrected mortality by the Abbott formula (1925).

\section{REFERENCES}

ABBOTT, W.S. A method of computing the effectiveness of an insecticide. Journal of Economic Entomology, v.18, n.2, p.265-267, 1925

BAUR, M.E. et al. Suppresion of diamothback moth (Lepidoptera: Plutellidae) with entomopathogenic nematode (Rhabditida: Steinernematidae) and Bacillus thuringiensis Berliner. Journal of Economic Entomology, v.91, n.5, p.1089-1095, 1998.

BOWLING, C.C. Rearing of two lepidopterous pests of rice on common artificial diet. Annals of the Entomological Society of America, v.60, n.6, p.1215-1216, 1967.

CRUZ, I.; MONTEIRO, M.A.R. Controle biológico da lagarta do cartucho do milho Spodoptera frugiperda utilizando o parasitóide de ovos Trichogramma pretiosum. Sete Lagoas: EMBRAPA Milho e Sorgo, 2004. 4p. (Comunicado técnico).

DUTKY, S.R. et al. A technique for the mass propagation of the DD-136 nematode. Journal of Insect Pathology, v.6, n.4, p.417-422, 1964.

FUXA, J.R. et al. Effect of host age and nematode strain on susceptibility of Spodoptera frugiperda to Steinernema feltiae. Journal of Nematology, v.20, n.1, p.91-95, 1988.

GARCIA, L.C. et al. Tecnologia de aplicação para os nematóides Heterorhabditis indica e Steinernema sp. (Rhabditida: Heterorhabditidae e Steinernematidae) para controle de Spodoptera frugiperda (Smith) (Lepidoptera: Noctuidae) na cultura do milho. Neotropical Entomology, v.37, n.3, p.305311, 2008. Available from: <http://www.scielo.br/ scielo.php? script=sci_arttext\&pid=S 1519 566X2008000300010\&lng=en\&nrm=iso\&tlng=en. Accessed: Apr. 22, 2010. doi: 10.1590/S1519-566X2008000300010>.

GREWAL, P.S. et al. Entomopathogenic nematodes: potential for exploration and use in South America. Neotropical Entomology, v.30, n.2, p.191-205, 2001. Available from: http://www.scielo.br/scielo.php?script=sci_arttext\&pid=S1519$566 X 2001000200001 \& \operatorname{lng}=$ en $\& n r m=i s o \& t \operatorname{lng}=e n$. Accessed: Apr. 22, 2010. doi: 10.1590/S1519-566X2008000300010.

KAYA, H.K.; HARA, A.H. Susceptibility of various species of lepidopterous pupae to the entomogenous nematode Neoplectana carpocapsae. Journal of Nematology, v.13, n.3, p.291-294, 1981.

KOPPENHÖFER, A.M. et al. Increased field and greenhouse efficacy against scarab groups with a combination of an entomopathogenic nematode and Bacillus thuringiensis. Biological Control, v.14, n.1, p.37-44, 1999.

MOLINA, J.P.; LÓPEZ, N.J.C. Producción in vivo de tres entomonematodos con dos sistemas de infección en dos hospedantes. Revista Colombiana de Entomología, v.27, n.1-2, p.73-78, 2001.

MOLINA-OCHOA, J. et al. Virulence of six entomopathogenic nematodes (Steinermatidae and Heterorhabditidae) on immature 
stages of Spodoptera frugiperda (Lepidoptera: Noctuidae). Vedalia, v.3, n.1, p.25-29, 1996

NERI, D.K.P. et al. Interação silício com inseticida regulador de crescimento no manejo da lagarta-do-cartucho Spodoptera frugiperda (J. E. Smith, 1797) (Lepidoptera: Noctuidae) em milho. Ciência e Agrotecnologia, v.29, n.6, p.1167-1174, 2005. Available from: <http://www.scielo.br/scielo.php?script=sci_arttext\&pid=S1413$70542005000600010 \& \operatorname{lng}=$ en\&nrm=iso\&tlng=pt. Accessed: Apr. 22, 2010. doi: 10.1590/S1413-70542005000600010>.

PARRA, J.R.P. Criação de insetos para estudos com patógenos In: ALVES, S.B. Controle microbiano de insetos. Piracicaba: FEALQ, 1998. p.1015-1037.
PFEIFER, T.A.; GRIGEIATTI, T.A. Future perspective on insect pest management: engineering the pest. Journal of Invertebrate Pathology, v.67, n.2, p.109-119, 1996.

SARMENTO, R.A. et al. Revisão da biologia, ocorrência e controle de Spodoptera frugiperda (Lepidoptera, Noctuidae) em milho no Brasil. Bioscience Journal, v.18, n.2, p.41-48, 2002 .

VALADARES-INGLIS, M.C.C. et al. Engenharia genética de microrganismos agentes de controle biológico. In: MELO, I.S.; AZEVEDO, J.L. Controle biológico. Jaguariúna: EMBRAPA, 1998. p.201-230.

WHITE, G.F. A method for obtaining infective nematode larvae from cultures. Science, v.66, p.302-303, 1927. 